科全書. 第三卷の二.

6) Kawamoto. u. (川本字之助)：同上

7) Kawakami, R. (川上理

一）：伾生學々遺傳病學，昭和七年.

u. Kehlkopf-Krhten. 1930.

8) Körner, 0. u. Grünberg K. : Lehrbuch d. Ohren-NasenKonstitutionellen Taubstummheit. Zentralbl. f. H. Bd. 14. H. 11. 1929.

10) Erbgang d. sporadischen, d. Ohrenheilkunde. 1908.

11) Schwarz: Die Diagnose d. erblichen Teubhe1t. D. m. W. 62 Jg. Nr. 3. 1936.

12) Tanaka, K. (田中一弘)：耳鼻咽喉科と遺傳病學, 耳鼻咽喉科, 六卷, 三號, 昭和 八年. 13) Derselbe.: 大日耳鼻, 三十九爸, 十一號, 昭和八年.

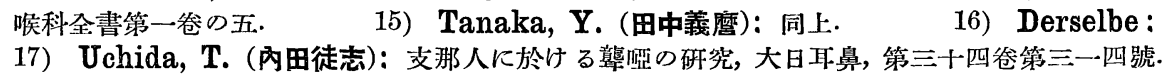

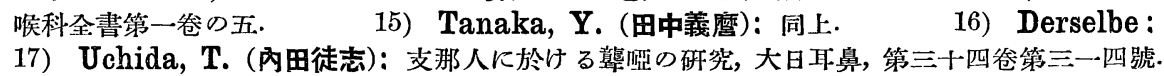

14) Derselbe : 日本耳鼻咽

16) Derselbe : 遺傳學, 1934.

Derselbe：日本耳鼻咽喉科全書第三卷の二.

\title{
鼻腔及び副鼻腔血癖腫に就て
}

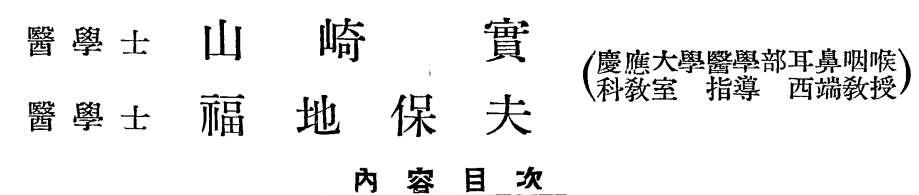
1. 緒 言
2. 症例
3. 考按
4. 統計的考察

\section{（1）緒 言}

血瘤腫(Blutbeule) なる疾患は本邦田所氏の命 名によるものにして，氏は大正 6 年，上顎實血 瘤腫己題し鼻閉，鼻出血を主徵とし進んでは惡 臭ある膿性鼻漏, 患側上顎顏面壁並びに口蓋の 膨隆, 眼球炨出及び屢々上顎部の放散性疼痛等 恰かも上顎惡性腫瘍に酷似せる症候を呈し, 然 多組織學的に何等惡性の像を見ざる臨床上一種 特異なる腫瘍ありとて其 3 例に就き詳細なる報 告をなし特に 臨床診斷上の注意を喚起されし が, 爾來本症の研究報告は年々相踵いで多く, 大正10年山本氏は斯る腫瘍を鼻腔內に認めて之 を鼻腔血瘤腫と稱したるが其後更に本腫瘍は上

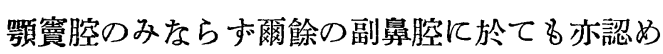
らるるに至れり．加之名稱は血瘤腫ならざるも 報告內容より恐らく本症と目さる可きものは既 に田所氏以前に於て明治23年岸氏の L中鼻道に
5. 結 諭
6. 附圖說明
7. 主要文獻

發生せる出血性鼻茸?，同43年上野氏の L出血性 鼻茸 2 例 ，同 45 年岡田氏の上上顎竇血管緎維腫 の 2 例? 等あり. 其後と踓も同樣なる報告を見 ること甚だ屢こなり。㼑つて泰西の文獻を調す るに未だ „Blutbeule“としての報告は之を知ら ざるが如きも1924 年 Raemer ; Rezidivierendes Haemoangiom d. Kieferhöhle. 1925年 Brüggemann; Haemoangiom d. Kieferhohle od. stielgedrehter Polyp. 1926 年 Gumperz; Ulzerieiter Haemoangiom d. Kieferhöhlenschleimhaut. 1930 年 Ter-Oganesjan ; 2 Fälle von Angiom d. Highmorshóhle. 等の症例は略々本症と同樣なるもの と見做す可きか.

其他血瘤腫題下に報告されたる症例のみにて 多約60を算し今や本症は必和し稀有なる疾患 之言ふ可からず. 殊飞白川 (昭和 7 年) 今井 (昭 和8年)等の詳細なる研究は洵に注目に值す可き 
๖のありと雖も, 本症の本態, 成因, 命名等に 關しては諸家の見解未だ必ホしる一樣ならず, 劣今後の研究に俟つ可き如尠しとせず. 余等 は先年所謂上顎實及び鼻腔血瘤腫と見る可き各 ふ 1 例に遭遇して比較的精細なる觀察を逐げ得 たるを以て，茲に其の概略を報告し以て從來の 文獻に追加すると共に聊加本症の統計的考察を 試みんと欲す。

\section{(2) 症例 \\ 第 1 例某，41歲，男， \\ 遣傳的前に家族的關係. К特記す可きものなし.}

躰往症. 生來健康にして醫治を乞ひし事なけれぞ も，领湎多量なりしと．20歲前後に淋疾に罹りしも徽 毒は否定す。

發病來歴. 昭和 4 年 6 月頃上り農業に從事する時屡々 顏面の浮腫を來せる事あり．同年12月始め頃上り左側 鼻閉を來し時々何等の 誘因なくして輕度の 鼻出血あ り. 出血に際しては疼痛其他の苦痛なく多くは數分乃 至十數分にして自ら止血せり．禁昭和 5 年 1 月某日畑 にて仕事中哭然輕度の脑量惑を覺え次で左側鼻より大 量の出血を來し即刻歸宅就床せるに約 2 時閒にして自 ら止血せしが柆朝上り再び少量の出血あり醫治を受け しも容易に止血せず． 3 日目賞院を訪れ即日入院す.

\section{現 症.}

一般的所見. 全身の骨格筋肉發育可良，㮡羕中等， 皮䖉は稍々荅白にして光澤を失ひ高度の貧血獎態にし て眼臉に輕度の浮腫を認む.心濁音界は僅に左方に擴 大し第二脑動脈昔の中等度六進あり。其他胸腹部に罢 常を認めず．反射正常，筧骨動脈は触診上レデルブา にして比較的緊張す，尿中に蛋白中等 ${ }_{\llcorner}$Blutcylinder? ¿Hyalinecylinder? 赫血球を證明す．血淸のレワ?氏反應 陰性なり。

局所的所見. 外鼻に形態的戀化を認めず．前鼻鏡檢 查を行ふに左側鼻腔々黑褐色の凝血樽腫瘍狀塊を以て 完全に閉塞さる.塊の前端は前鼻孔に趠し表面秒々不

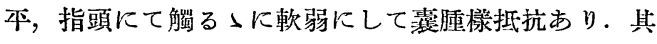
の被膜栐物の一部破孔て血性粘液性の惡臭ある濃厚液 絕えず浸むが如くに出で，鉬子文は消息子を以て觸る れば容易に出血す，强ひて消息子を以て檢するに中鼻
道倒壁に於て强き抵抗あり。甲介は腫瘍狀塊に掩はれ て認むる事能はず，中隔は强く右方に彎曲す，後鼻鏡 檢査を行ふに黑褐色にして一部灰白色を帶びたる腄㿋 狀塊は殆んぞ後鼻孔に充滿し, その周圍には少量の膿 汁附着す．左側上顎部骨壁の膨隆，眼球突出，口蓋の 膉隆，颚下腺腫脹等は認められず. 唯左眼麥粒腫あり て流涙多きを見る。疼痛は一般に缺如す。右側鼻腔は 異常なく上顎簣穿刺の結果亦陰性なり.

診 斷. 尿檢查の結果, 內科的には急性絲捄體䝳炎 を有す．而して上远所見より恐らく左側鼻腔或は上颃 䁇血瘤腫ならむと診斷せるも份惡性腫澺を否定す可か らず．然れども腫瘍が極めて出血性なるを以て試驗的 切除を止め旁, 治療の目的を以て柆日 Caldwell-Luc 氏 法により上䫈竇開放を行ふ。

手術所見 左側犬齿裳の骨壁に異常なく厚さ尋常, 骨壁開放と同時に血性污穢色濃厚液噴出するが如くに 出ず。該液を拭去するに鼗は稍々廣閵, 粘膜は一般に 浮腫性に肥厚せるも著しからず，上內壁部に於て所々 Polyp 狀に拾殖し中に膿樣物を㵔溜せるあり，內側鼻 腔との隔壁は一般に骨壁消火し灰白色の結締織樣膜の みを見る、特に中鼻道聰門部の粘膜は自然孔を中心と して廣く墑死狀に崩潰し其中心部は鼻腔內の腫瘍狀塊 內部に通じ其他には筫外部との交通むるを認めず.

茲に於て本症が所謂血瘤腫にして慢性上颚䩀炎を伴 ふものなるを磪知し筫內より鼻側壁の一部と共に鼻腔 內腫瘍の大部を摘出, 寶粘膜を剥離して㓣口を綎合し 更に鼻腔內より腫愓の殘部を完全に摘出し得たり．其 際該腫瘍は中鼻道に於て上颚䁇内に交通せる外，固有 鼻腔内には療着なく下岉介は下方に厚せられながら中 等度の肥大を示せり．中鼻道は罢常に廣蕳となり其側 壁粘膜は髙死状となれり。中甲介は菱綃して前上方に 僅に其殘骸を認む。手術中出血は多からず.

經 過. 手術後出血僅少, 只數日閒膿性鼻汁稍々多 き經過良好にして術後約 1 ケ月, 貧血も略々恢復し て退院, 其後異常なし.

腫痬の肉眼的所見. 摘出せる腫瘍は二三に破潰され たれど，大さ約小なる鴙卵大，前後に稍々長く形不本 にして鼻腔の鑄型の如し，其の前方 $1 / 3$ 部は表面暗赤 色比較的本滑にして囊腫樣軟，後方 $2 / 3$ 部は表面粗徏 大部分灰白色結蠻織性の組緎にて被はれ前部に比して 遥に硬し然れぞも雨者の境界は明磪ならずして該結䋨 織狀組繊は所々分枝狀に前方軟部に移行す，割面一般 
に暗赤色脆弱なる凝血狀を呈し僅に其の周邊部の强固 なる灰白色結締織漾物質によ口圍繞され, 之が所々索 狀に腫瘍內部に向って進入し, 之に低て腫瘍內は数房 に分たれたる觀すり，腫瘍の中心に近き部は所々軟化 し或ひは腔胴を形成して中に血性污穢濃厚夜を容る。

第 2 例. 山田某, 45 歲, 男, 農業.

家族的遗傳的. に認む可きものなし.

躰往店. 比較的健康にして輕度の感冒の外, 著患を

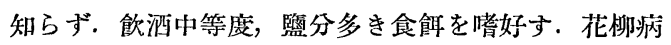
は絕對に否定せり.

發病來歷. 昭和 4 年 7 月頃上 $り$ 時々輕度の右側鼻出血 ありしも，自覺的何等笘痛なき故放置せるに同年10月 頃上り右側鼻閉塞を來せり。柆昭和 5 年 1 月末頃より 鼻閉塞甚だしく出血亦漸く其量及頻度を加一輕度の右 侧眼永笑出，流涙，右側煩部の輕き放散性疼痛等を來 し，地方醫により內服を持續せるも症狀輕快せず，依 つて昭和 5 年 7 月當院を訪机入院す.

\section{現 症.}

一般的所見. 全身の骨格筋肉發育可良なるも營養稍 不良，皮䖉は僅に荅白にして光澤を失ひ惡液質樣賓血 狀態なれども浮腫發疹等を認めず.胸腹部に著變なく， 反射正常, 體溫脈膊正常, 尿便に異常なく, 血清 $\llcorner ワ\urcorner$ 氏反應陰性，輕度の動脈硬化は認むるも一般に出血性 體質と認むべきものなし。

局所的所見. 右側煩部は左側に比し稍々膨隆し眼球 突出著明にして流滬多し． 口蓋は右第 2 大臼齿の内方 約 $1 \mathrm{~cm}$. の部に於て 示指頭大の膨出を示し，指罍すれ ば軟餅栐の抵抗を感ず. 右側顎下腺の雀卵大に腫脹せ るもの數個あり，耳咽喉頭に異常を認めず.

前鼻鏡檢查. 右側鼻腔は，側壁の强く脸出して甲介 と共に中隔側に密接せるを以て，殆んぞ闒塞され，中 鼻道其他の所見は不明となれど，其間より獎液性血栐 の惡臭ある分泌物絕えず前鼻孔に洩出せるを見らる。

媵鼻鏡檢查. 右側中鼻道側壁は內方に向ひ强度なる 膨出を來し，表面は肉芽樣或ひはしポリープ栐に肥大 せるが如きも膿汁多き䉆め其像明かならず. 右側下鼻 道より寶の試驗的穿刺を行ひしに惡臭ある多量の血性 膿汁を獲たり。

左側鼻腔は異常なく, 筫の試驗穿刺亦陰性なり.

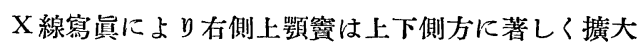
し，一様に暗影を呈す.

診 斷. 以上所見より本患者は右側上顎䫦の惡性腫
瘍? 血瘁腫? の疑問の下に入院，第 3 日目，右側上顎 簤の開放手術を施行す.

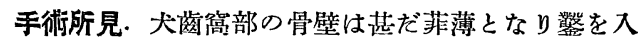
る〉中䆙粘膜容易に破机惡臭を放ちて暗褐色の血性粘 液多量に流出す．筫は廣潤にして中には唯暗褐色濃厚 液を充たし，其の塤壁に近き部は稍々固き㠜血樣塊と なり，更に其外側部は强固なる結綿䋨樣索狀物質に移

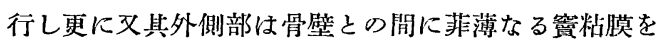
認めたるも，他に腫瘍の如きものを見ず.

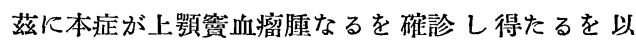
て，先ず腫瘍壁を剔出し，更に殘存せる趩粘膜を制離 して下鼻道に對孔を作札り。

手術中更に詳細に觀察せるに，製壁は一般に異常に 擴張され，下眼菒壁は僅に紙樣菲薄なる骨板を殘存す. 下側壁には第 2 大囦炵の內側に賞りて示指頭大の骨壁 缺損あり，腫瘍の一部は之より口腔に向つて膨出せる を認めたり．鼻倒壁亦殆んど骨壁を缺如せり．更に上 下側壁の笣粘膜中には腫癔壁々㽷着して區別し得ざる 部あり或は菱縮消失して之を認め得ざる部あり，斯の 如く腫瘍は極度に膨大して全責腔を滿たし，更に骨壁 を厘迫破潰して寶外に兴出せる狀態なるが故に，其の 原發部位は確認し難し々雖も嘖の自然孔附近及び篮骨 蜂菒部に數個の夏豆大の鼻茸ありて, 腫愓壁は此部に 於て强固に瘾着されたるを觀れば恐らく此部に原發せ るものならむ. 手術經過中出血は多からず.

經 過. 術後出血少し, 約 2 週間の笽內洗滌に際し て少量の出血ありしのみ. 約1ヶ月にして全治退院す.

腫湯の肉眼的所見. 本腫瘍は手術に際して破潰され 部分的に剔出したるを以て全體の大さ不明なるも擴張 せる患側上顎㝘內容に略々一致するものにして其內部 は軟化して廣大なる一腔胴を形成し中に暗褐色の血性 濃厚液を滿たせるものなり．其の周壁の厚さは $0.3 乃$ 至 $0.7 \mathrm{~cm}$. 表面並に割面の性狀は第 1 例と異る所なし.

組織學的所見. 前記二例の手術によりて獲たる種々 の材料に就て可及的精密なる組織學的檢索を試みたる が既に諸氏の報告されし所と大罳なきを以て之を省 略し只其の大要をのみ記さん.

\section{第 1 例 鼻腔血癌腫}

腫瘍組䋨の末梢部は一般に壤死性となり染色不良に して基質不明，上皮，血管及び腺を認めず. 斯る周櫋 部を除く內方の大部分は新舊種々の出血䆠にして所々 年輸狀を呈し其の內方に赴く程新鮮なる出血を認む. 
腫瘍の最中心部旣ち中鼻道基底部は軟化して腔胴をな

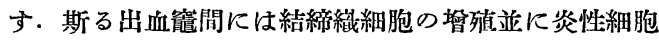
浸潤著明なり，血管は出血籠の中心たる腫瘍基底部に 於て稍々多く認められ何れも極度に管壁擴張し其形亦 不規則にして一見海綿狀血管腫に似たるも特に血管新 生の像著明ならずヌ一部血栓を形成し中に Canalisation の所見亦認め得た $り$.

患側上顎䁇粘膜は一般に慢性焱の所見を呈し殊に管 自然孔附近にては上皮の一部粘液性變性に陷 り粘膜下 層には血管異常に多く之亦搌張充盈し或ものは管壁破 れて組織內及筫內に出血せるを認む。

\section{第 2 例. 上顎竇血痹腫}

本例は手術時部分的に摘出せる腫瘍壁各部及蜜內粘 膜各部に就て檢索せるが第 1 例と異るは腫癔壁全般に 涉りて血管の擴張せるもの多し．警内粘膜は一部上皮 の扁平化せる外，第 1 例と大坡なく，只本例に於ては 自然孔上部上り摘出せる鼻茸様粘膜內にも亦海綿栐血

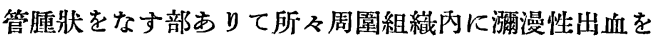
認めたり。

\section{(3) 考按}

上述 2 例は其臨床的特異の所見に依りて田所 氏の所謂血瘤腫なるの診斷签易なりしが，摘出 せる腫瘍は已に退行性變化强く組織學的所見に 於て基組織の何たるや容易に斷定す可からす。. 然れども兩側共に結締織の增生著明にして，一 部擴張せる血管に富み Haemoangioma cavernosum に似たるも血管の新生著明ならざるを以 て寧亏 Billoth 氏の Fibroma cavernosum 飞算 入す可きものならむ.

茲に於て其成立を按亦るに本 2 例に於ては豫 め慢性上顎嘪炎を有して賔自然孔附近より比較 的血管に富める鼻革を生じたるるのが，第 1 例 に於ては鼻腔に出で,第2例は竇內に留りたるも のと思考さる. 而して竇粘膜炎症の進行は該鼻 茸にも波及し或は鼻茸內に膿瘍を形成して其队 部に分布せる血管壁亦一定の炎性變化恣起する に到るや，何等かの動機に依りて先づ血管壁と
一部破綻を生じ鬆粗なる鼻咠組織內に出血せる ならむ。次で斯る出血の持續或は反復するや更 に當然腫瘍內部の血行障碍を來して血栓も生す 可く又腫瘍の容積を增大して未梢部は泟次壞死 に陷りしものなる可く，患側上顎賔壁及鼻腔內 の變化は該腫瘍の增大!よる二次的變化ならん と解さる. 余等っ 2 例は共に農を業とする勞働 者にて然か子第 1 例は慢性腎炎及び輕度の動胍

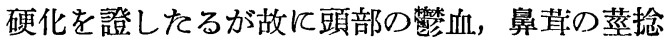
轉等を坴起す可き動機により最初の鼻革內出血 を來せるものなるべきは想像に難からず。

分余等は上記 2 例患者の手術前後各 22 包に 涉りて血液學的諸檢查を試みたるが認む可き特 殊の所見はなかりしを茲に附記す。

\section{（4）統計的考察}

田所氏以來血瘤腫名稱の下に報告されし症例に余等 の 2 例を加へて總數 60 症例を涉獵し得たるが，其內， 性別の制明せるは53例，左右側記載するは41例，職業 の明示されたるは25例にして，即ち次の如き數を得た y.

\begin{tabular}{|c|c|}
\hline 性 別 & 耐男 \\
\hline 則 別 & \\
\hline 職 業 別 & 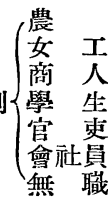 \\
\hline
\end{tabular}

即ち男性は $58.5 \%$ 弱にして女性上り稍々多く，左側は $65.8 \%$ 强にして右側に比して倍數に近き頻度を示す. 職業中，農業60\%，女工12\%にして，勞働者に本症の 斷然多く見らる〉は注目に價すべく，本应の成因に關 して䇨働が或役割を演ずるにはあらざるか，今後つ症 例に於て留意す心゙き點なりとす。

年齢は最低 13 歲(田所), 最高70歲(伊藤)にして10歲 以下の幼若者を除きては殆んぞ年齡を問はずと雖も， 就中青壯年期に於て最も多し.

腫瘍の基組織，血瘤腫の基組織は本症の名稱の如何 
をも左右するものとして從來諸家の諭議つ焦點となり し觀あり．既往应例中制明せるを分類す机ば，

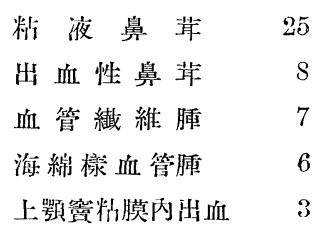

となるも此內に多少諸家つ病理學的見解の相遗あるを 以て必ずしも正笉を期し難し

出血の動機に就ては從來軲々の報告あり郘ち基組

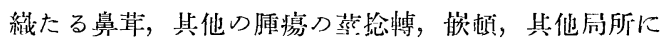

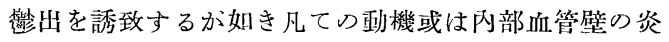
性變化等は其主なるものにして，近時患者の血夜性狀 の罢常(今井), 女子に於ては月經(䰻洲)も亦注意され し所なり。

之を要するに，血瘦腪の本態たる基組絨は（各症例 に於て）決して一浆なるものに非ずして，本㱏が㑏理

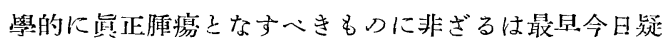
開の除地なきも, 臨床的には本应獨特の諸应狀ありて,
從來の一般出血性鼻苒と明かに區別すへく，吾人䧗床 家の診斷並に治療の上には依然血瘤腪 (Blutbeule) な る名稱を附するを以て至便なりと思考す。

\section{（5）結論}

(1) 余等の 2 例は臨床的所見より 1 は鼻腔,

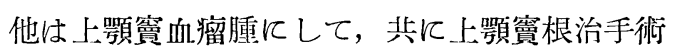
により血瘤腫を摘出全治せしめたるものなり。

（2）本2例に於て血瘤胵の基組䪭は Billoth氏 の Fibroma caveınosum に一致せるものにして, 其に出血の動機は不明なり。

（3）統計上本症は勞働者に多く，又右側に比 して左側に多し.

（4）血瘤腫なる名稱は基組織の如何を問はず 臨床上の名稱として使朋するを使宜なりとす。

(擱筆するに常り組絨學的檢索に際して木下教授の 御懇管なる御敎示を深謝す)

\section{附 圖 說 明}

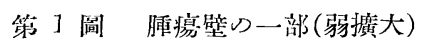

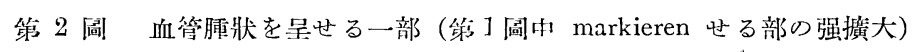

\section{全 要 文 獻}

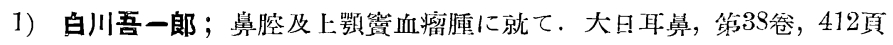

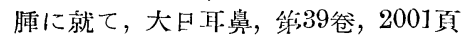

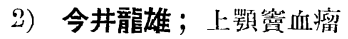


山崎, 福地論文附圖

第

- 圖

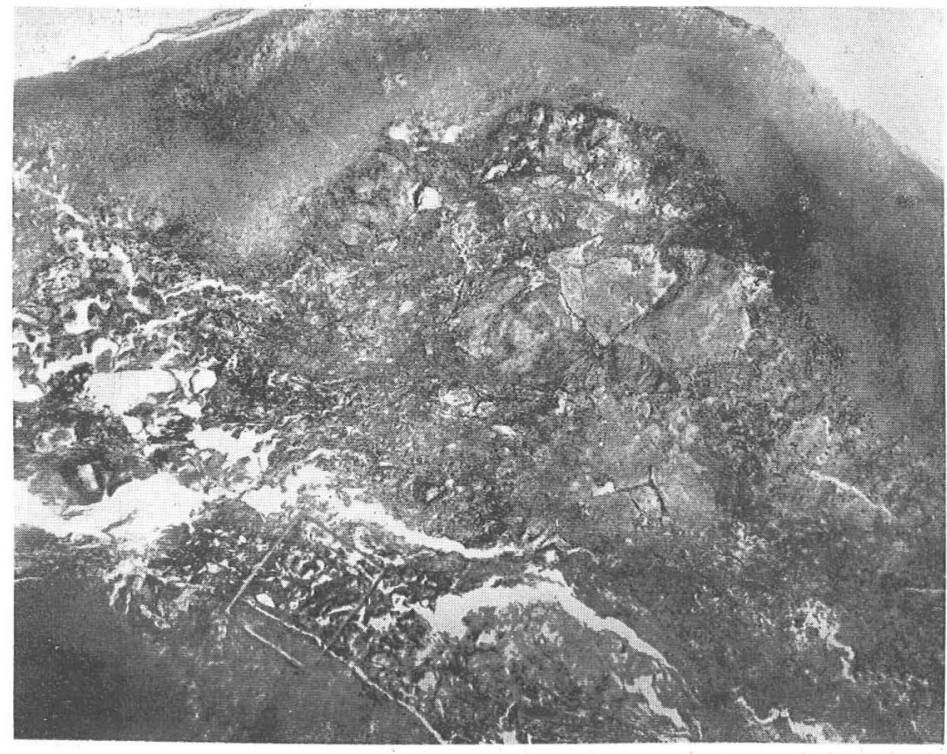

第

$$
\text { 二 圖 }
$$

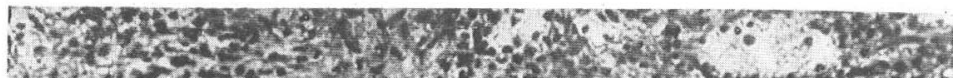
S.

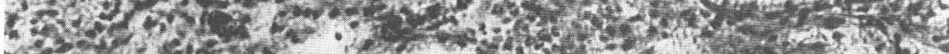

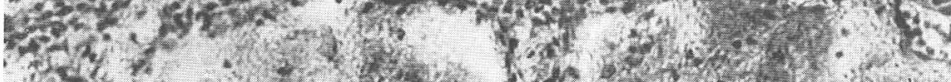

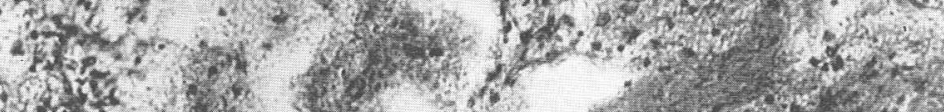

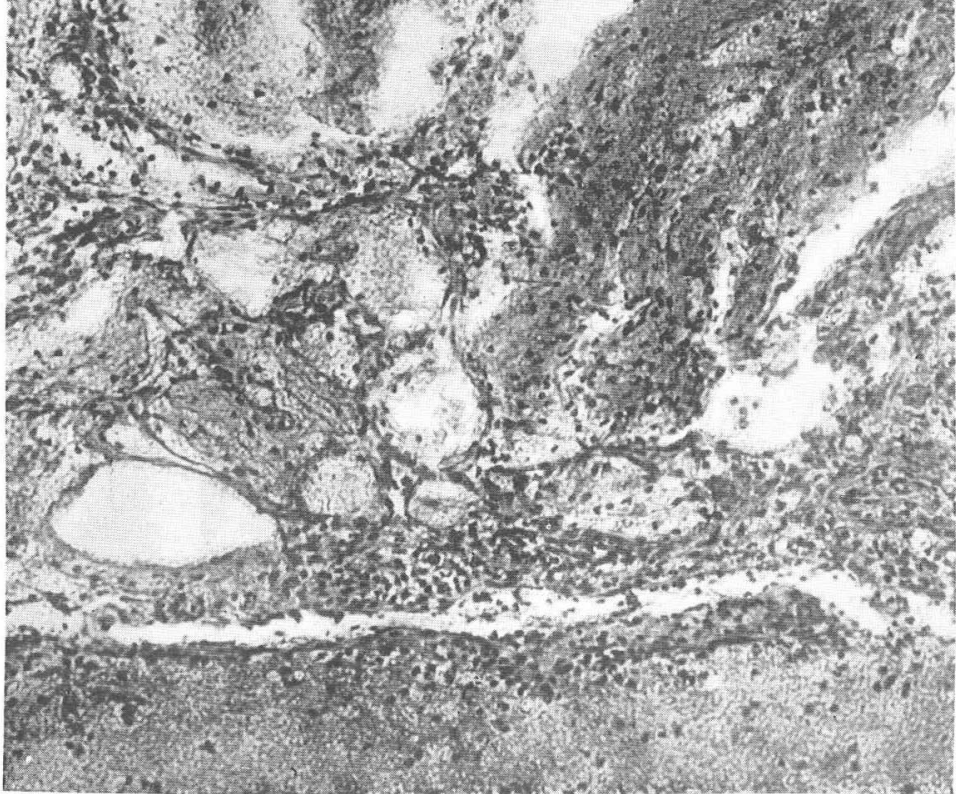

